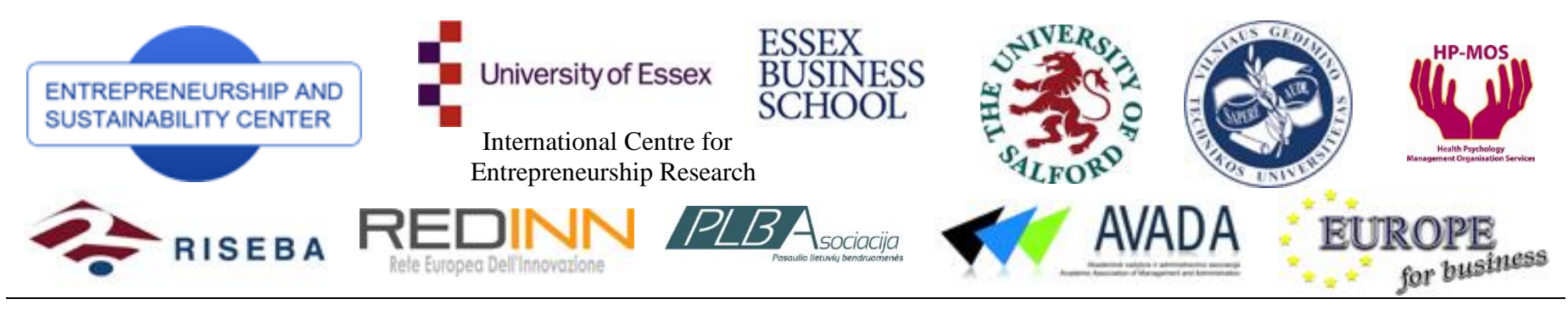

The International Journal

ENTREPRENEURSHIP AND SUSTAINABILITY ISSUES

ISSN 2345-0282 (online) http://jssidoi.org/jesi/aims-and-scope-of-research/

\title{
PECULIARITIES OF YOUNG SPECIALISTS ON LABOUR MARKET: CASE OF LATVIA
}

\author{
Olga Starineca ${ }^{1}$, Inesa Voronchuk ${ }^{2}$ \\ University of Latvia, Aspazijas bul. 5, LV-1050 Riga, Latvia \\ E-mails: ${ }^{\text {lolga.starineca@lu.lv; (corresponding author); }{ }^{2} \text { inesa.voroncuka@lu.lv }}$
}

Received 20 November 2014; accepted 15 January 2015

\begin{abstract}
The youth unemployment issue is topical for European countries. The authors would like to outline what kind of risks Latvia can meet in different sectors of economy focusing on the public sector. Authors summaries published experts reflections on the situation on Latvian labour market, analyse statistical data, use Latvian economically active youth (high schools students and young specialist with higher education aged from 18 until 24). The hypothesis is Latvian young specialists are mostly attracted by service private sector organisations as employers rather than the public sector organisations.
\end{abstract}

Keywords: Youth Unemployment, Public Sector, Generation Y

Reference to this paper should be made as follows: Starineca, O.; Voronchuk, I. 2015. Peculiarities of Young Specialists on Labour Market: Case of Latvia, Entrepreneurship and Sustainability Issues 2(4): 198208.

DOI: http://dx.doi.org/10.9770/jesi.2015.2.4(3)

JEL classification: E24, J13, O15

\section{Introduction}

European young specialists are under the examination in various fields of science. Physiologists, anthropologists, psychologists, sociologists, economists and other scientists try to define peculiarities of the generations. From the economy and management point of view, it is important to examine and evaluate young specialists as employers and job seekers. Definition of the young specialists' behaviour on the labour market and in organisations, their interaction with their potential and actual employers is a significant activity to make any decision on youth employment.

The youth unemployment issue is topical for European countries. The authors would like to outline what kind of risks Latvia can meet in different sectors of economy. The authors observe challenges in different sectors of economy focusing particularly on the public sector. Previous the authors' analysis showed that there are public sector organisations that employees' average age is above 45-50 years. Public sector organisations are weak in attracting young specialists (Voronchuk, Starineca 2014); therefore, it is reasonable to provide help to these organisations to reduce a risk of local specialists' lack. For instance German 'graduates with better networks are more likely to find a job and less likely to migrate' (Krabelab, Flöthera 2012; Fratesi 2014). This conclusion shows the perspective on the further action of public organisations, where communication with young employees has a key role. One of the risks also outlined in the quote is migration. If the local employers do not attract young specialists, they can find a job abroad, as the majority of them are skilled and educated enough (Vinķele 2013) 
for the modern international or at least European labour market requirements.

The objective of this article is to define possible risks on Latvian labour market connected to the Latvian young specialists' peculiarities. Authors summaries published experts reflections on the situation on Latvian labour market, analyse statistic data, use Latvian economically active youth. The hypothesis set by the authors is Latvian young specialists are mostly attracted by service private sector organisations as employers rather than the public sector organisations. The authors also describe the difficulties that appeared trying to test the defined hypothesis.

\section{Previous research}

Many researchers are devoted to the youth unemployment issues around the world. "The problem seems fierce not only because jobless youth is expensive for the society - EUR 153 billion or $1.2 \%$ of the GDP in the EU in 2011 - but also because it affects the future of it" (Artner 2013; Bilevičienè, Bilevičiūte 2015). The youngest generation should be motivated and respect the country that provides them job in terms of being fear further on paying taxes that is an important part of the economy. For instance on the South Asia the industrial structure whether public or private is in shambles thereby failing to absorb a big chunk of educated youth of the state. Due to weak or no private sector, the educated unemployed youth of the state have cloned themselves only towards government sector which is already disguised and seems to have reached a point of saturation in terms of absorption of educated manpower (Khan 2014). In Europe, there is another problem. The majority of the young people are professionally educated or getting the higher education (Central Statistical Bureau of Latvia 2014 a,b,c,d).

In some cases, the educational system where main focus is given on theory rather than on practical knowledge (Sofi, Yasmin 2011; Išoraitè 2013; Tarabkova 2014) can cause the young specialists with higher education incompetence on the labour market. One more important aspect that needs to be outlined is generation Y specialists' lack of job experience (Vargas 2013; Dzemyda, Raudeliūnienè 2014; Tarabkova 2014). Often organisations need a competent and experienced specialist right now, they are not ready, they do not want and they do not have time to mentor new young and unexperienced employee.

Youth in the labour market is quite vulnerable category; the issues of providing effective employment that are matters of public policy. Of course, the decision of this problem is impeded in the social, economic, legal and political spheres of our live, so the appropriate measures should be adopted correspondingly (Grigoryeva 2012). To evaluate youth unemployment from the economy and economics point of you the statistical data and economic indexes are the main sources of information. Sometimes statistical data providers can neglect or have unexplainable range of data. 'In almost all instances, the unemployment rate for teenagers (aged 15 or 16 years to 19 years) is consistently higher than that for 20- to 24-year-old' (Grigoryeva 2012). Some scientists use an age range of 18-34 years to study youth unemployment. However, they split unemployment data to two groups: people under 25 and over 25 (Cinalli, Giugni 2013). Sometimes there are simply not the most suitable, relevant and correct data for the appropriate analysis of the youth unemployment.

Collecting necessary data scientists may use surveys. To survey educated unemployed youth usually scientists (Sofi, Yasmin 2011) implemented random sampling method or secondary analyses of quantitative data that is obtained from the WEB pages of the organisations (Grigoryeva 2012). The respondents on the survey by Sofi and Yasmin (2011) were contacted in their respective homes. Youth unemployment has been evaluated also from the policies point of view. 'Youth unemployment has been taken into account by EU institutions since the last decade, and different initiative have been adopted to tackle this serious societal problem.' One of the conclusions of this research is "because of the incremental dynamics of policymaking and the differing preferences of European institutions, member states, social partners and social NGOs, there is still no well-defined youth unemployment policy model at EU level" (Lahusen et al. 2013).

Some countries such as Latvia are active on entrepreneurship culture creation to stimulate young people establish work places either for themselves, and to create new job places for other unemployed people. Entrepreneurship gives youth a sense of ownership and participation in economic (Ali 2014). However, not all 
new established enterprises provide jobs according to the demand. The by Investment and Development Agency of Latvia studied the many organisations from the foreign investors' perspective. They found out that in terms of Latvian aging society, the cluster of some specialist are also aging. Already now, there is a lack of specialists in Latvia in such areas as (Studente 2014):

- Green technologies

- Health care

- IT global business

- Life Sciences

- Metalworking, mechanical engineering and electronics

- Transport and logistics

- Treatment of foods and some other.

Some areas are under the risk that on the nearest future there will not be any young specialist, who can replace the retired ones in various fields. Latvia and many other countries are moving to the knowledge economy and we might have employment problems. The labour market offer and demand often do not match. The decision might go from the analysis of the complex factors that may include political, economic, and social and education aspects.

\section{Methods / Theoretical Framework}

The authors describe the framework and methods used to design their empirical study. The main aspect of the theoretical framework is Generation Y approach. The authors also describe the content and structure of the questionnaire for the survey as well as its implementation limitations.

\subsection{Generation Y employees and job seekers}

The majority of publications available in English devoted to the generation Y (Millennials) are from the periodicals. Private organisation's and private and public enterprises' managers usually are the target audience of these articles. Their objection is to give tips and suggestion on how to communicate or establish relationship with youngest generation of employees. The idea that 'organizations have a responsibility to help managers understand how workers' expectations have changed and how they can adapt their leadership style to these new conditions' (Bawany 2014) can substantiated this objection. The Generation Y includes in large number of today's youths (Bawany 2014), therefore, it is important being aware of some peculiarities of young specialists as generation Y representatives.

Generation Y or Millennials are usually defined as people born from 1980 till 2000 (Martin 2001; Sheahan 2006; Matthewman 2011; Ārste-Avotinna, Lieǵis 2013; Hills et al. 2013) Previous researches on the generation Y as job seekers and employers' stakeholders showed that Latvian young specialists have their requirements to the potential and current employees. They are asking for high their input and work performance evaluation, attractive working environment, attention and recognition as well as professional development opportunities (Starineca 2014). Sean Conrad (2009) gives the same characteristics of young engineers. He outlines that young specialists are recent graduates therefore they do not have enough experience in a field that requires providing mentoring and feedback activities for them. In addition, they evaluate E-Systems used by their potential employers. The most important common topic that they are interested during the selection interviews are: performance management, professional development, and performance assessment (Conrad 2009).

The most frequently outlined topics crucial for generation Y employees and job seekers in the observed by the authors' articles are (Conrad 2009; Ware 2014; Duff 2009; Ferri-Reed 2013; Hills et al. 2013):

- Adaptation to their interests and values

- Automating of operational and management processes

- Career path

- Challenging working environment

- Information Technologies (IT) usage

- Mentoring for new employees 
- Performance assessment system

- Professional development opportunities, etc.

Meaning of the generation y young employees is essential. They are striving for professional development and fast career growth. They are open for new knowledge and experience, it is important for them to be evaluated and awarded as well as quite, if the employer does not meet their values and requirements. In addition, they like to use IT for each working and learning process to ensure its fast fulfilment. Learning process of the young generation becomes easier because of the helpful developed of technologies. They are also fast learners and curious people. They are striving for getting educated informally or formally entering higher education institutions. Not only technological approaches influence this generation Y representatives, but also other factors. They are accustomed to e-communication. Generation Y employees easily use e-learning opportunities and like rather interactive training than formal lectures (Tyler 2008). They love freedom and responsibility, expect consistent and positive feedback, and use technology transparently. This means instant, constant communication using "flat" hierarchies (Alexander 2014). They like to be a centre of an event, receive attention from employers', managers', and colleagues' side.

The authors concluded that it could be easy to attract young specialists as any survey respondents, if the survey connected with them and issues that they care about. As this is the first generation to grow up completely within the age of the internet and have come to be known as digital natives (Camp 2014), it will be easier to reach them using e-communication tools or other Internet environment approaches. Recalling that they expect external recognition and approval (Camp 2014) as the survey respondents they would expect to receive any kind of benefit or at least recognition.

\subsection{Knowledge economy concept}

The knowledge economy as a term appeared about 1970. Peter Drucker (1992) wrote that the next society will be a knowledge society. Knowledge will be its key resource, and knowledge workers will be the dominant group in its workforce (Lingenfelter 2012). There is a tendency of number of people with higher education increase in Latvia. For the last seven years, the level of economic activity of the Latvian economically active inhabitants is around 82\% (Central Statistical Bureau of Latvia 2014a). The authors outlines that knowledge-based economy includes several basic spheres. By White et al. (2012) knowledge-based economy is based on Open Innovation, Education, Knowledge Management, and Creativity. These components are set on information and communications technology infrastructure (Voronchuk, Starineca 2014a). The World Bank has a little bit different defined components of knowledge economy. Measuring knowledge of the countries, the World Bank presumes that knowledge economy is built on four pillars: Economic Incentive and Institutional Regime (EIR), Innovation and Technological Adoption, Education and Training, and Information and Communications Technologies (ICT) Infrastructure. The main variables groups (functional cuts) that the World Bank uses assessing knowledge are: Overall Performance of the Economy, Economic Incentive and Institutional regime (Economic Regime, Governance), The Innovation System, Education and Human resources (Education, Labour), ICT (The World Bank 2012).

The common criterion that counts considering knowledge economy by both practitioner and schoolers is education. Employment in the knowledge based economy is characterised by increasing demand for more highly-skilled workers (OECD 1996). Therefore, the having a higher education is a necessity nowadays in developed and developing countries that are on the way of transition to the knowledge-based economy. The authors use this approach to have an evidence of the study population correct definition. The authors examine not every Latvian young person rather only those that are striving for the higher education (students) or already have it (higher educational institutions' graduates).

\subsection{Empirical study's difficulties}

Population definition is based on the knowledge economy aspects, defined object of the study and international statistical norms as well as Latvian laws. The population of the research is defined as higher education institu- 
tions' students and young specialist with higher education $\left(1^{\text {st }}\right.$ and $2^{\text {nd }}$ level professional higher education, bachelors, masters, doctors) in age from 18 until 24 years. Knowledge economy concept influenced a choice of young people in the population. Knowledge economy presumes the tendency of society to the knowledge including formal education. In Latvia at the beginning of the academic year 2013/2014 there were 89671 students that is $4.43 \%$ of all Latvian inhabitants (Central Statistical Bureau of Latvia 2014b). 62.93\% (56 430) of that students were young people in age from 18 till 24 years (Central Statistical Bureau of Latvia 2014a). From 1998 till 2013 344236 students got qualification or degree. Despite of demographic and economic issues since 2002 the number of higher education institutions' graduates is about 20 thousends each year (Central Statistical Bureau of Latvia 2014d). It was important to include into the research population students and people with higher education assuming that some of them can be both students and higher education institutions' graduates.

The age framework of the population was defined according to some considerations (Fig. 1). According to the education system in Latvia young people can enter higher educational institution from the age 18 not 19 as the Cabinet of Ministers (2013) defines it, if a children went to school at age of six not seven as it is assumed. It is possible to enter school at age of six.

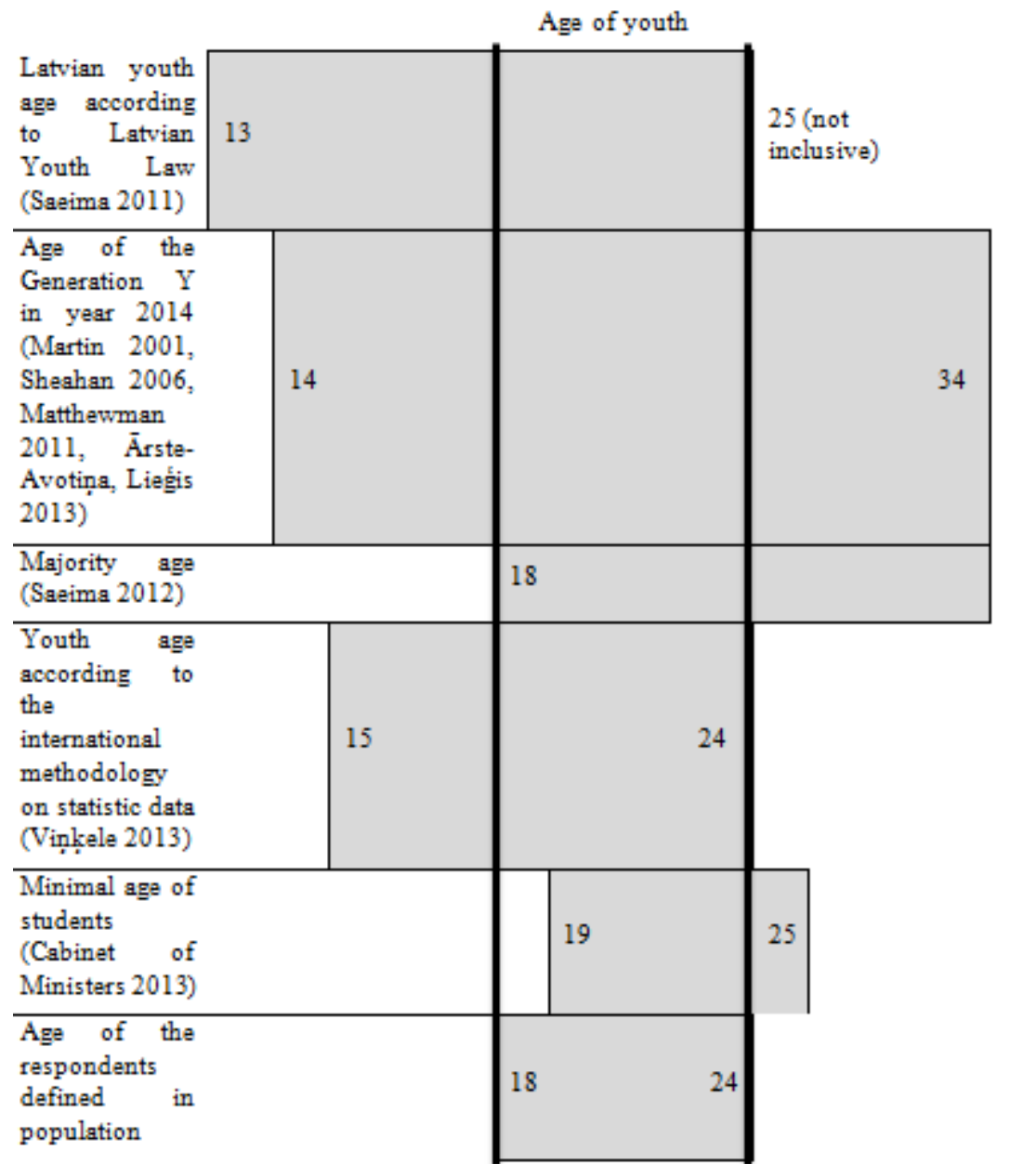

Fig.1. The research population's age framework

Source: Authors' created

According to the education system in Latvia young people can enter higher educational institution from the age 18 not 19 as the Cabinet of Ministers (2013) defines it, if a children went to school at age of six not seven as it is assumed. It is possible to enter school at age of six. International methodology of statistics presumes that young people are at the age from 15 until 24 years (Vink,ele 2013). The authors highlight that this defined group do not represent the relevant and real situation, when presenting data about the youth employment. In addition, the Cen- 
tral Statistical Bureau of Latvia (2014a) presents at their informative overview that young people under 18 are unemployed, because they are studying, that proves the Latvian society transition to the knowledge economy. Therefore, it is pointless to include youth younger than 18 years as they are not the fully engaged into the labour market processes. The objective of the study also supports this consideration as the authors focus on students of higher education institutions and their graduates only. The youngest higher education institutions' students at the each educational level in Latvia can be at the age from 19 until 25.

Summing up all factors taken into consideration the authors defined the population by the age framework. The respondents of the survey should be at the age from 18 until 24 years. There are some challenges that the authors met. Wishing to reach the defined population the authors choose to calculate the sample of the research. The method of the sample is random. However, before the sample needs to be divided to the strata proportionally by gender, region and age. The first challenge is a lack of information. There are no data on the population by each criterion. It makes impossible even to calculate the sample. The next challenge is connected to the difficulty of reaching the defined population. Organisations that are dealing with data collection could not propose any methodologically correct approach to survey people from the defined population. They outlined that it can be possible only in long run, i.e., it can take several years to collect data. Otherwise, they can propose to use a local social network that does not cover justified sample from the defined population.

The most realistic approach to reach higher educational institutions' students is to approach them directly during the studies; however, it makes difficulty to reach the appropriate sample of the higher educational institutions' recent graduates. The next approach, which can be used to spread questionnaires among the Internet users as the probability that Latvian young people from the defined population are the Internet users are high. Besides, Latvian youth from the defined population represent the most technically savy generation ever, millennials are already transforming the workplace through their extensive use of the Internet and social media for communication (Ferri-Reed 2013). The organisations that collect data have a possibility to spread questionnaires as pop-ups on several popular among Latvian inhabitants Internet sites. This process, however, is also timeconsuming. Besides these challenges, of course there is one more aspect - financial one that trigs the process of data collection.

\subsection{Questionnaire content and structure}

The questions that the authors have formulates depend on the authors survey objectives. Further, the authors explain a role of each question from the questionnaire developed. The authors mainly would like to check the background of the respondents from the population to find out what kind of specialists are on the labour market. It will help to understand the risk of some industries that need to 'refresh' their staffs. The questionnaire begins the introduction that includes information on the reason to participate into the survey and the survey purpose, survey results further usage plans and terms, as well as clear instruction on the questionnaire filling in.

The first block of questions is about the respondents habits on searching for a job. This section helps to collect data that characterises Latvian youth from the set population as job seekers, inquiring some there as job seekers peculiarities. One of the first questions is about the aspects that are important for young Latvian job seekers with higher education choosing an employer from the three main aspects that have been already studied by the authors: Employer Brand, Social Responsibility, and Employers' Ratings (Voronchuk, Starineca 2014a,b,c; Starineca, Voronchuk 2014). All these three issues are interconnected. The respondent needs to assess each aspect using 10 points scale, where one is not absolutely important and 10 is important very much. A 10 points scale is used along the entire questionnaire, where the respondent needs to evaluate something by the importance.

The next question is on the regular (usual) sources that the respondents use searching for a job. The authors use check boxes to let the respondents select one or more options. The options are:

- Advertisements at university (e.g. on information desks, on WEB page)

- Job /career fairs/ job days (employers' exhibitions)

- Friends/relatives 
- Job search engines on advertisements' portals (like cv.lv, cvmarket.lv, ss.lv, etc.)

- Organisations' doors open days

- Particular organisations' WEB pages

- State Employment Agency WEB page

- If other, the respondents are asked to specify.

The authors also ask the respondents additionally to point out, what kind of job search engines they use, if they checked that they use any, answering on the previous question. The next question is based on the previous the authors' studies results that highlight some aspects that usually are lacking in the Latvian public administrative organisations' job advertisements (Starineca 2014; Voronchuk, Starineca 2014a). The respondents need to assess, how different kind of information is important for them to consider applying for an offered position using 10 points scale. The answers on this question will help the authors to identify disadvantages of administrative public organisations' job advertisements, if they lack of any information that is highly important for the respondents. The last question in this section inquires, do the Latvian youth from the set population like to work for a private sector organisation or rather for one from the public sector. This is a multiple-choice question. This question's answers will reflect the Latvian youth orientation to the employers from the one particular sector currently.

The block of the personal information on the gender, age, place of living, occupation, and education background finish the questionnaire. The authors also clarify the field of study of the students from the sample and field of work of the employed students and graduates. This is a multiple-choice question. The answer's options are collected according the authors previous researches and or are based on the researchers and study results of other researchers or organisations mentioned before in this article. There are few questions for the currently employed respondents splitting them into two groups - who work on the position according to their professional background and who are working in the other sphere. One question requires answering, if the respondent would like to change his/her current working place. The scale proposed for the answering on this question is from undoubtable no, rather no, I have never thought about it before until rather yes, and undoubtable yes. It will help to check the Latvian generation Y employees' characteristics. It states in the scientific and popular-scientific literature that generation Y representatives are not loyal to their employees and easily change working places, if they are not satisfied with the current one. Therefore, the next question clarifies how the respondents are satisfied with the current employer. Answering on the question the respondents may use the assessment scale from undoubtable unsatisfied until satisfied very much.

There are also additional question for those, who are working with a public organisation. Here the authors inquire the motivation of the public sector organisations young employees to work for their employers (it is an open question that asks to mention at least two impetuses or reasons of the choice). The authors also check, if the respondents know about professional development and learning activities proposed by their employers and what kind of them are proposed, if any (e.g., external or internal seminars, workshops, training, etc.). It is a checkbox question. The authors also clarify, if this group of respondents have specific education on Public administration or any other. The questionnaire consist of fourteen sets of questions. The questionnaire is quite detailed and long for those, who are either a students, employees, and work for public organisation. Not all respondents need to answer all questions.

\section{Results, discussion and limitations}

The authors did not manage to carry out the survey planned. The challenges described before disturbed to reach the set objective of the study fully. The authors only summarised the overall studies results to define some possible risks on Latvian labour market that connected to the Latvian young specialists' peculiarities. The focus of the authors was a public sector. The authors mostly evaluated the challenges that public administrative organisations can have.

The authors could not check what kind of requirements Latvian young people from the defined population have to their potential employers; evaluate their motivation to work for public organisations in Latvia; and inquire the 
main aspects that they pay attention on and that are important for them considering on application for a vacant position in an organisation. However the authors expect to have some form the list that was defined out of previous researches, (they are also included as a checkbox answers in the developed questionnaire):

- A room for creativity on the working place

- Benefits

- Career/Professional growth possibilities

- Challenging tasks

- Covered business trips

- Distant work possibilities

- Fast Career/Professional growth possibilities

- Flexible working hours

- Insurance

- Learning opportunities

- Personal working equipment with possibility to use them outside working hours (e.g. a smartphone, laptop, car, etc.)

- Professional development possibilities

- Salary

- Salary that partly depends on the working results

- Social and medical benefits

- Work in a multicultural environment.

The main risks that authors can already define are migration of the local educated workforce, a necessity to outsource some specialists from different areas. Lack of specialists in some areas causes a need of employees outsourcing or liaising (it is questionable, if Latvian organisations will be ready to attract specialists from abroad). There could be a risk that young specialists can manipulate some areas organisations. It arises a questions 'Could they force it, won't it arise a new macroeconomic challenges?' Organisations could need to raise some costs on their employees that can influence many macroeconomical issues and cause the economy and economic instability again.

\section{Conclusions}

Sometimes data on youth unemployment is exaggerated or not proper enough to make the adequate conclusions. To solve the issue the separate researches should be carries out. Not always even state is interested in the detailed issues analysis. The essence of one problem could be a hidden and unexpected chain of other challenges caused by the negligent attitude or wrong activity towards the issue.

The authors have examined several previous studies on the topic from the methodological and contextual point of view. The authors also developed and adapted the questionnaire based on some previous considerations and researches results on the topic. Nevertheless, the authors did not manage to find financial support and implement the survey because of challenges on the proper survey implementation possibilities. The survey fulfilment requires many financial and time resources to ensure high quality of it.

The main conclusions that can make the authors are connected to the examined problem connection to the education system and traditions. Most probably in the nearest future higher education of young specialists needs to be more practical, e.g. devoting more time for learning on the working place. It can become more popular because of the employers requirements and youth peculiarities. Education required by the labour market most probably could become even broader not specific, so graduates from the one study program could work not only by their direct specialisation.

Generation Y employers can be characterised as not loyal to their employers, perceptive and greedy to new knowledge and experience, technologies driven, active and fast. The authors have a hypothesis that also Latvian generation Y young specialists have the same characteristics as other young specialists - generation Y represent- 
atives described in the observed publications. Therefore, Latvian administrative public organisations most probably are not that attractive for the young specialists from the defined population that creates additional risk for them to have a lack of specialists in the nearest future.

\section{References}

Alexander, S. 2014. The New World Reality of Benefits Communication, Employee Benefit Plan Review 68(11): 13-14.

Ali, M. 2014. Youth Unemployment, Harvard International Review 36(1): 13.

Ārste-Avotiṇa, A. ; Lieǵis, V. 2013. Jaunā Y paaudze [New Generation Y], Forbes Latvia (11): 82-83.

Artner, A. 2013. Is Youth Unemployment Really the Major Worry? Debatte: Journal of Contemporary Central and Eastern Europe 21(23): 183-205. DOI: http://dx.doi.org/10.1080/0965156X.2013.863998

Bawany, A. 2014. Generation Y, Leadership Excellence 31(8): 6-7.

Bilevičienè, T.; Bilevičiūte, E. 2015. Influence of employment on strategy of sustainable development implementation, Journal of Security and Sustainability Issues 4(3):520-535. DOI: http://dx.doi.org/10.9770/jssi.2015.4.3(3)S

Camp, W. 2014. Strategies for working with Generation Y employees, Canadian Manager 39(1): 24.

Centrālās statistikas pārvalde [Central Statistical Bureau of Latvia]. 2014a. Darbaspēka apsekojuma galvenie rādītāji $2001-2013$ [Labour Force Surveys, Years 2001-2013] Latvijas Republikas Centrālā statistikas pārvalde. Available on the Internet: http://www.csb.gov.lv/sites/default/files/nr_17_darbaspeka_apsekojuma_galvenie_raditaji_latvija_2001-2013_gada_2014_00_lv.pdf

Centrālās statistikas pārvalde [Central Statistical Bureau of Latvia]. 2014b. Studentu skaits pa izglīīibas tematiskajām grupām augstskolās un koledžās (mācību gada sākumā) [Number of students by thematic groups at universities and colleges]. Centrālās statistikas pārvaldes datu bāze. Available on the Internet: http://data.csb.gov.lv/pxweb/lv/Sociala/Sociala_ikgad_izg1/IZ0270.px/table/tableViewLayout1/?rxid=cdcb978c-22b0-416a-aaccaa650d3e2ce0

Centrālās statistikas pārvalde [Central Statistical Bureau of Latvia]. 2014c. Augstskolu un koledžu studentu sadalījums pēc vecuma un dzimuma [High school and college students in a breakdown by age and gender]. Centrālās statistikas pārvaldes datu bāze. Available on the Internet: http://data.csb.gov.lv/pxweb/lv/Sociala/Sociala_ikgad_izgl/IZ0241.px/table/tableViewLayout1/?rxid=cdcb978c-22b0$\underline{416 \mathrm{a}-\mathrm{aacc}-\mathrm{aa} 650 \mathrm{~d} 3 \mathrm{e} 2 \mathrm{ce} 0}$

Centrālās statistikas pārvalde [Central Statistical Bureau of Latvia]. 2014d. Grādu vai kvalifikāciju ieguvušo studentu skaits pa izglītības tematiskajām grupām augstskolās un koledžās [Degree or qualification, the number of students by thematic groups at universities and colleges]. Centrālās statistikas pārvaldes datu bāze. Available on the Internet: http://data.csb.gov.lv/pxweb/lv/Sociala/Sociala_ikgad_izg1/IZ0290.px/table/tableViewLayout1/?rxid=cdcb978c-22b0-416a-aacc$\underline{\text { aa650d } 3 \mathrm{e} 2 \mathrm{ce} 0}$

Cinalli, M.; Giugni, M. 2013. New challenges for the welfare state: The emergence of youth unemployment regimes in Europe? International Journal Of Social Welfare 22(3): 290-299. DOI: http://dx.doi.org/10.1111/ijsw.12016

Conrad, S. 2009. Feedback loop, Mechanical Engineering 131(8): 24-25.

Drucker, P. F. 1992. The Age of Discontinuity: Guidelines to Our Changing Society. Transaction Publishers. 420 p.

Duff, A. 2009. Born supreecy, Director 63(2): 47.

Dzemyda, I.; Raudeliūniené, J. 2014. Sustainable youth entrepreneurship in conditions of global economy toward energy security, Entrepreneurship and Sustainability Issues 1(4): 247-256. DOI: http://dx.doi.org/10.9770/jesi.2014.1.4(7)

Ferri-Reed, J. 2013. Quality, Conflict, and Communication across the Generations, Journal for Quality \& Participation 35(4): 12-14.

Fratesi, U. 2014. Editorial: The Mobility of High-Skilled Workers - Causes and Consequences, Regional Studies 48(10): 1587-1591. DOI: http://dx.doi.org/10.1080/00343404.2014.955689

Grigoryeva, N. 2012. The Problem of Youth Unemployment in Rural Area, Agris On-Line Papers In Economics \& Informatics 4(1): 312 . 
Hills, C.; Ryan, S.; Warren-Forward, H.; Smith, D. R. 2013. Managing 'Generation Y' occupational therapists: Optimising their potential, Australian Occupational Therapy Journal 60(4): 267-275. DOI: http://dx.doi.org/10.1111/1440-1630.12043

Išoraite, M. 2013. Motivation tools though lenses of prospective employees, Entrepreneurship and Sustainability Issues 1(2): 116-123. DOI: http://dx.doi.org/10.9770/jesi.2013.1.2(6)

Khan, B.A. 2014. Occupational Structure of Kashmir: A Case Study of Block Kupwara, European academic research 2(6): 7671-7690.

Krabelab, S.; Flöthera, C. 2012. Here Today, Gone Tomorrow? Regional Labour Mobility of German University Graduates, Regional Studies 48(10): 1609-1627. DOI: http://dx.doi.org/10.1080/00343404.2012.739282

Lahusen, C.; Schulz, N.; Graziano, P. R. 2013. Promoting social Europe? The development of European youth unemployment policies, International Journal of Social Welfare 22(3): 300-309. DOI: http://dx.doi.org/10.1111/ijsw.12011

Lingenfelter, P. E. 2012. The Knowledge Economy: Challenges and Opportunities for American Higher Education, in Oblinger, D. G. (Ed.). Game Changers: Education and Information Technologies. EDUCAUSE, 9-23. Available on the Internet: http://net.educause.edu/ir/library/pdf/pub72031.pdf

Martin, C.A. 2001. Managing Generation Y: Global Citizens Born in the Late Seventies and Early. HRD Press Inc. 105 p.

Matthewman, J. 2011. The Rise of the Global Nomad. Kogan Page. 216 p.

Ministru kabinets [Cabinet of Ministers]. 2013. Kārtība, kādā izsniedz valsts atzītus augstāko izglītību apliecinošus dokumentus [Procedures for issuing state-recognized certificates of higher education]. Likumi.lv. Available on the Internet: http://likumi.lv/doc.php?id=256157/

OECD. 1996. The Knowledge-Based Economy Organisation for Economic Co-operation and Development. 46 p. Available on the Internet: http://www.oecd.org/science/sci-tech/1913021.pdf

Sheahan, P. 2006. Generation Y. Hardie Grant Publishing. 363 p.

Sofi, B. A.; Yasmin, E. 2011. Magnitude of Educated Unemployment among Rural Youth of Jammu and Kashmir: A Case Study of Pulwama District, Advances In Bioresearch 2(2): 126-132.

Starineca, O. 2014. Generation Y Potential Employees - A Public Sector Stakeholder. The 72nd conference of the University of Latvia, February 3, Riga, Latvia. Available on the http://www.evf.lu.lv/fileadmin/user_upload/lu_portal/projekti/evf//konferences/lu72konference/publ_sekt_parvald/Olga_Starineca.pdf

Starineca, O.; Voronchuk, I. 2014. Employer Branding Training Development for Public Organisations, Regional Formation and Development Studies 3(14): 207-219. DOI: $\underline{\text { http://dx.doi.org/10.15181/rfds.v14i3.877 }}$

Studente, L. 2014. Darba tirgū trūkstošās un pieprasītās profesijas [Labor market gaps and the required professions]. $L V$ portāls 'Par likumu un valsti'. Available on the Internet: http://m.lvportals.lv/likumi-prakse.php?id=263705

Tarabkova, L. 2014. Model of motivating linked-up with education, Entrepreneurship and Sustainability Issues 2(1): 12-18. DOI: http://dx.doi.org/10.9770/jesi.2014.2.1(2)

The World Bank 2012. Knowledge Economy Index (KEI) 2012 Rankings. The World Bank. 9 p. Available on the Internet: http://siteresources.worldbank.org/INTUNIKAM/Resources/2012.pdf

Tyler, K. 2008. Generation Gaps, HR Magazine 53(1): 69.

Vargas, J. 2013. Generation Y Yearns for Challenging and Satisfying Government Work, Public Manager 42(2): 15-17.

Viņķele, I. 2013. Informatīvais ziņojums par jauniešu garantijas īstenošanu Latvijā 2014-2018 [Informative report on the implementation of the Latvian youth guarantee]. Available on the Internet: http://www.lm.gov.lv/upload/jauniesiem/lmzin jg 171213.pdf

Voronchuk, I.; Starineca, O. 2014. Knowledge Management and Possibilities of Professional Development in Public Sector, European Integration Studies (8): 168-179. DOI: http://dx.doi.org/10.5755/j01.eis.0.8.6844

Voronchuk, I.; Starineca, O. 2014. Social Responsibility Initiative Implementation in Public Sector in Latvia, Social Research (Reviewed and submitted for publication).

Voronchuk, I.; Starineca, O. 2014a. Human Resource Recruitment and Selection Approaches in Public Sector: Case of Latvia. Interna- 
tional Scientific Conference 'New Challenges of Economic and Business Development - 2014' Conference Proceedings. May 8-9, Riga, Latvia, 417-430. Available on the Internet: http://www.evf.lu.lv/uploads/media/001-476_Conference_Proceeding_A4.pdf

Ware, B. L. 2014. Stop the gen Y revolving door, $T+D$ 68(5): 58.

White, D.S.; Gunasekaran, A.; Ariguzo, G. 2012. The Structural Components of a Knowledge-Based Economy, International Journal of Business Innovation and Research 7(4): 504-518. Available on the Internet: http://dx.doi.org/10.1504/IJBIR.2013.054872http://dx.doi.org/10.1504/IJBIR.2013.054872

Olga STARINECA. MSM, PhD student, a Senior Teacher Assistant at Stockholm School of Economics in Riga on an HRM course for bachelor students. Research interests: Public Administration, Human Resource Management, Social Responsibility, Youth Policy, Youth Unemployment, Geberation Y as Employers and Job Seekers, Creating Shared value, Teaching Adults.

Inesa VORONCHUK. Dr.oec., Professor, a Head of the Department of Public Administration, Demography and Socio-Economic Statistics. Research interests: Public Administration and Human Resource Management, Finance, Higher Public Education.

This is an open access journal and all published articles are licensed under a Creative Commons Attribution 4.0 International License 